\title{
Морфогенез органа нюху східної довгошийої черепахи (Chelodina longicollis)
}

\section{Дарина Шкабура, Ярослав Степанюк}

Волинський національний університет імені Лесі Українки, Луцьк, Україна Адреса для листування: Stepanyuk.Yaroslav@vnu.edu.ua

Резюме. Вивчення розвитку нюхового аналізатора рептилій є дуже важливим в еволюційному та порівняльно-анатомічному аспектах. Нюховий аналізатор різних рептилій має суттєві відмінності в будові. У ящірок та змій нюховий аналізатор анатомічно розділений на основну та додаткову (вомероназальну) системи. Нюховий орган черепах має відмінні риси організації. У більшості черепах в нюховому органі відсутнє морфологічне розмежування основного нюхового та вомероназального органа.

У роботі описано ключові стадії розвитку структур нюхового органа східної довгошийої черепахи (Chelodina longicollis). Нюховий орган складається з присінка, власне нюхової порожнини та носоглоткового каналу, який відкривається в ротову порожнину хоанами. Носова порожнина розмежована вузькою ділянкою несенсорного епітелію на дорсальну частину, яка вистелена нюховим епітелієм, та вентральну, яка вистелена вомероназальним епітелієм. Вентральна частина носової порожнини утворює медіальне впячування, що значно збільшує об'єм вомероназального епітелію. Нюховий епітелій має чисельні залози Боумена, які відсутні у вомероназальному епітелії. Протока латеральної нюхової залози впадає на межі переходу присінка в носову порожнину та зволожує основний нюховий епітелій, який найбільше контактує $з$ повітрям. Доказом наявності вомероназальної системи у черепахи слугує наявність вомероназального нерва, окремі волокна якого йдуть від вентральної частини носової порожнини до медіальної поверхні нюхової цибулини.

Ключові слова: черепахи, нюховий орган, основний нюховий епітелій, вомероназальний епітелій.

\section{Morphogenesis of Olfactory organ of the eastern long-necked turtle (Chelodina longicollis).}

\section{Daryna Shkabura, Yaroslav Stepanyuk}

Lesya Ukrainka Volyn National University, Lutsk, Ukraine

Correspondence: Stepanyuk.Yaroslav@ vnu.edu.ua

Abstract. The study of olfactory analyzer development of reptiles is very important in evolutionary and comparative-anatomical aspects. The olfactory analyzer of different reptiles has significant differences in morphology. The olfactory analyzer of lizards and snakes is anatomically divided into the main and accessory (vomeronasal) systems. The olfactory organ of turtles has distinctive features of organization. There is no morphological separation between the main olfactory and vomeronasal systems in the olfactory organ of most turtles.

The article describes the key stages of olfactory structures development of eastern long-necked turtle (Chelodinalongicollis). The olfactory organ consists of vestibulum, nasal cavity and nasopharyngeal duct, which opens into the oral cavity through choanae. The nasal cavity is divided by a narrow section of non-sensory epithelium into a dorsal part, which is lined by olfactory epithelium, and ventral, which is lined by vomeronasal epithelium. The ventral part of the nasal cavity has medial diverticula, which significantly increases the volume of the vomeronasal epithelium. The olfactory epithelium has numerous Bowman's glands, that are absent in the vomeronasal epithelium. The duct of the lateral olfactory gland opens at the place of transition of the vestibulum into the nasal cavity. This gland moisturizes the main olfactory epithelium, which is most in contact with air. The presence of the vomeronasal nerve, individual fibers of which depart from the ventral part of the nasal cavity and enter the medial surface of the olfactory bulb, confirms the existence of the vomeronasal system in turtles.

Keywords: turtles, olfactory organ, main olfactory epithelium, vomeronasal epithelium. 


\section{ВСТУП}

Нюховий орган $є$ у всіх чотириногих i виконує ольфакторну та респіраторну функції. Суттєві морфологічні зміни в нюховому органі відбулися при виході хребетних на сушу. Відомо, що нюховий орган риб вистелений нюховим епітелієм, який вкриває нюхові ламели. У більшості амфібій виділяють основний нюховий та додатковий (вомероназальний) епітелій. Нюховий орган рептилій як перших справжніх наземних хребетних зазнав найсуттєвіших змін. Він анатомічно розділився на основну нюхову систему, яка представлена основним нюховим епітелієм, та додаткову нюхову систему (вомероназальну), яка представлена вомероназальним органом (орган Якобсона). Крім того в нюховому органі з'явилися залози, які зволожують сенсорний епітелій.

Відомо, що периферичний відділ нюхового аналізатора черепах морфологічно відрізняється від решти рептилій [1]. Нюховий аналізатор черепах розділений на основну та додаткову нюхові системи, проте вони не утворюють окремих ізольованих структур [1]. Порожнина носа більшості черепах умовно розділена на нюхову та вомероназальну області [2; 3]. Вважають, що вомероназальний епітелій виконує функцію водної хеморецепції, пов'язаної 3 харчовою, соціальною та репродуктивною поведінкою, тоді як нюховий епітелій вловлює одоранти 3 повітря $[1 ; 4 ; 5]$. На сьогодні до кінця не 3'ясовано причини виникнення та значення вомероназального органа у хребетних.

Метою нашої роботи було дослідити морфогенез структур нюхового органа у східної довгошийої черепахи Chelodina longicollis (Shaw 1794) та з'ясувати наявність структур додаткової (вомероназальної) нюхової системи.

\section{МАТЕРІАЛИ Й МЕТОДИ ДОСЛІДЖЕНЬ}

Для даного дослідження була використана колекція тотальних мікропрепаратів ембріонів східної довгошийої черепахи C.longicollis Природничого музею Тюбінгенського університету Еберхарда Карла (Senckenberg Centre for Human Evolution and Paleoenvironment at Eberhard Karls Universität, Tübingen, Germany). Для дослідження особливостей розвитку нюхового органа досліджуваного виду було взято ембріони різних стадій розвитку (табл. 1).

Ембріони фіксовані в розчині нейтрального формаліну. Зрізи ембріонів східної довгошийої
Характеристика досліджуваного матеріалу

\begin{tabular}{|c|c|c|c|}
\hline $\begin{array}{c}\text { Колекційний } \\
\text { номер } \\
\text { препаратів, № }\end{array}$ & $\begin{array}{c}\text { Довжина } \\
\text { голови } \\
\text { (CL), мм }\end{array}$ & $\begin{array}{c}\text { Кількість } \\
\text { проаналізованих } \\
\text { зрізів, n }\end{array}$ & $\begin{array}{c}\text { Товщина } \\
\text { зрізів, } \\
\text { мкм }\end{array}$ \\
\hline IW 1216 & 7,8 & 146 & 10 \\
\hline IW 1224 & 14 & 239 & 10 \\
\hline IW 1225 & 18 & 235 & 10 \\
\hline
\end{tabular}

черепахи зафарбовані азаном за методом Гайденгайна. Серійні зрізи товщиною 10 мкм проведені у поперечній площині.

Фотографування серійних зрізів проводили у Природничому музеї Тюбінгенського університету Еберхарда Карла на мікроскопі Olympus CH-2 з цифровою камерою Canon EOS $650 \mathrm{D}$.

3D-моделі органів нюху створені за допомогою комп'ютерної програми Amira v.5.0 на основі серійних цифрових фотографій [6].

\section{РЕЗУЛЬТАТИ ТА ЇХ ОБГОВОРЕННЯ}

Дефінітивний нюховий орган більшості черепах порівняно 3 іншими рептиліями має простішу будову і складається із трьох частин присінка, власне нової порожнини та носоглоткового каналу з внутрішніми ніздрями (хоанами) [2].

\section{Стадія 7,8 мм}

Присінок має трубчасту форму, проте позбавлений порожнини i ростролатерально відкривається зовнішніми ніздрями назовні. Стінки присінка товсті, утворені слабо диференційованими несенсорними клітинами. У місці з'єднання присінка 3 власне носовою порожниною в дорсальну стінку присінка впадає протока складної трубчастоальвеолярної латеральної носової залози (рис. 1). Каудально присінок переходить у найбільшу частину нюхового органа - власне носову порожнину, яка має щілиноподібну форму i витягнута у дорсовентральному напрямку. Стінки порожнини вистелені сенсорним епітелієм. Верхня частина порожнини (2/3 площі) вистелена товстим сенсорним епітелієм - це основний нюховий епітелій, а нижня тоншим нюховим епітелієм це вомероназальний епітелій (рис. 1). Нюховий та вомероназальний епітелії розмежовані вздовж усієї носової порожнини стоншенням його стінок. Власне носова порожнина вентрально переходить у короткий носоглотковий канал (рис. 4). 
a

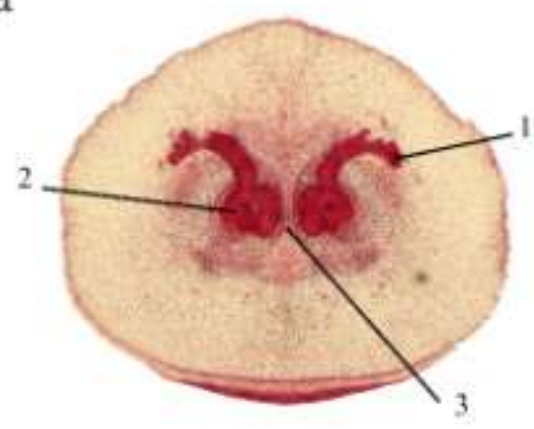

500 Mाल

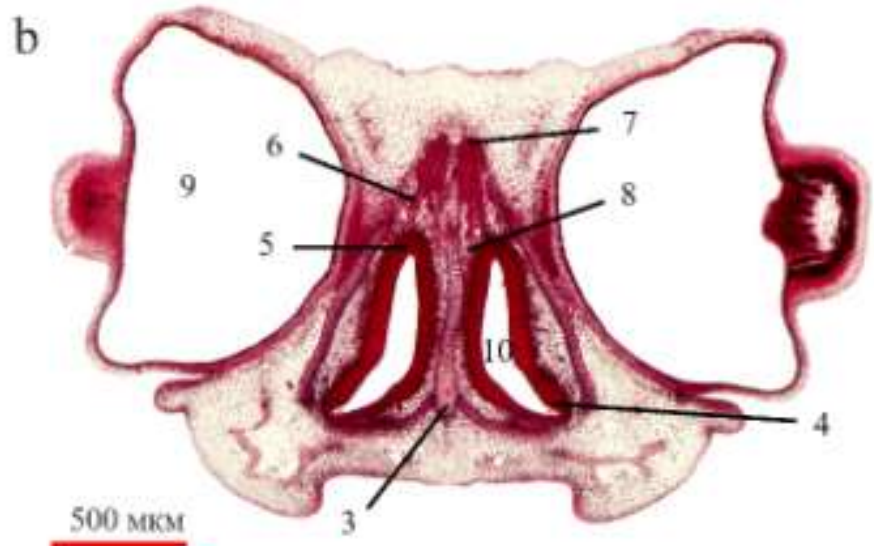

Рис. 1. Поперечний переріз через присінок (a) та носову порожнину (b) C. longicollis на cтадіï розвитку 7,8 мм: 1 - латеральна носова залоза; 2 - присінок; 3 -носова перегородка; 4 вомероназальний епітелій; 5 - основний нюховий епітелій; 6 -нюховий нерв; 7 - волокнистий шар нюхових иибулин; 8-вомероназальний нерв; 9 -око; 10 -носова порожнина.

Канал має власну порожнину, яка вентрально відкривається у ротову порожнину внутрішніми ніздрями - хоанами. Правий та лівий нюховий орган розділений хрящовою носовою перегородкою.

Від нюхового епітелію, який вистилає верхню частину нюхового органа, відходять чисельні волокна нюхового нерва, який ростроветрально входить у нюхові цибулини. Від вентральної частини нюхового мішка відходить вомероназальний нерв, який залягає між нюховим органом та носовою перегородкою. Волокна вомероназального нерва разом із волокнами нюхового нерва входять у нюхові цибулини (рис. 1).

\section{Стадія 14 мм}

Присінок збільшує свою товщину за рахунок суттєвого збільшення товщини його стінок (рис. 4). По всій довжині присінка 3'являється ледь помітна порожнина, яка в місці переходу у власне носову порожнину значно збільшується в розмірах. У місці переходу присінка у власне носову порожнину впадає протока латеральної носової залози, яка значно збільшується в розмірах. Збільшення розмірів латеральної носової залози відбувається внаслідок збільшення секреторних одиниць. У результаті таких змін залоза набуває дифінітивного вигляду. Об'єм власне носової порожнини помітно збільшується порівняно з попередньою стадією. В епітелії дорсальної частини носової порожнини з'являються залози Боумена. У місці контакту основного нюхового епітелію 3 вомероназальним відсутній сенсорний епітелій (рис. 2). На початку носової порожнини у вомероназальній області утворюється медіальне впячування (рис. 2). На дні вентральної частини носової порожнини відбувається перегрупування вомероназального епітелію, в результаті чого дно носової порожнини втрачає епітелій. Каудально вентральна частина нюхової камери випинає латерально. Нюховий та вомероназальний нерви збільшуються в розмірах.

\section{Стадія 18 мм}

Ширина присінка значно збільшується за рахунок розростання власної порожнини, а його довжина навпаки зменшується (рис. 3; рис. 4). Зовнішні ніздрі зміщуються і займають ростродорсальне положення. Ростральна частина порожнини присінка повністю вистелена несенсорним епітелієм. У каудальній частині присінка несенсорний епітелій вистилає лише дорсальну його частину. Рострально нюховий епітелій присінка стає тоншим, а каудально потовщується і вистилає лише дорсальну частину носової порожнини. Під слизовою оболонкою присінка знаходиться товстий шар гладких м'язових волокон. Найбільша товщина гладкої мускулатури в місці переходу присінка у носову порожнину. В місці переходу присінка у носову порожнину впадає протока латеральної носової залози, а вентральна та дорсальна стінки утворюють складки (рис. 3).

Носова порожнина збільшується в розмірах порівняно 3 попередніми стадіями (рис. 3; рис. 4). Вентральна частина нюхової носової порожнини зміщується латерально, в результаті чого набуває овальної форми. Межа переходу 

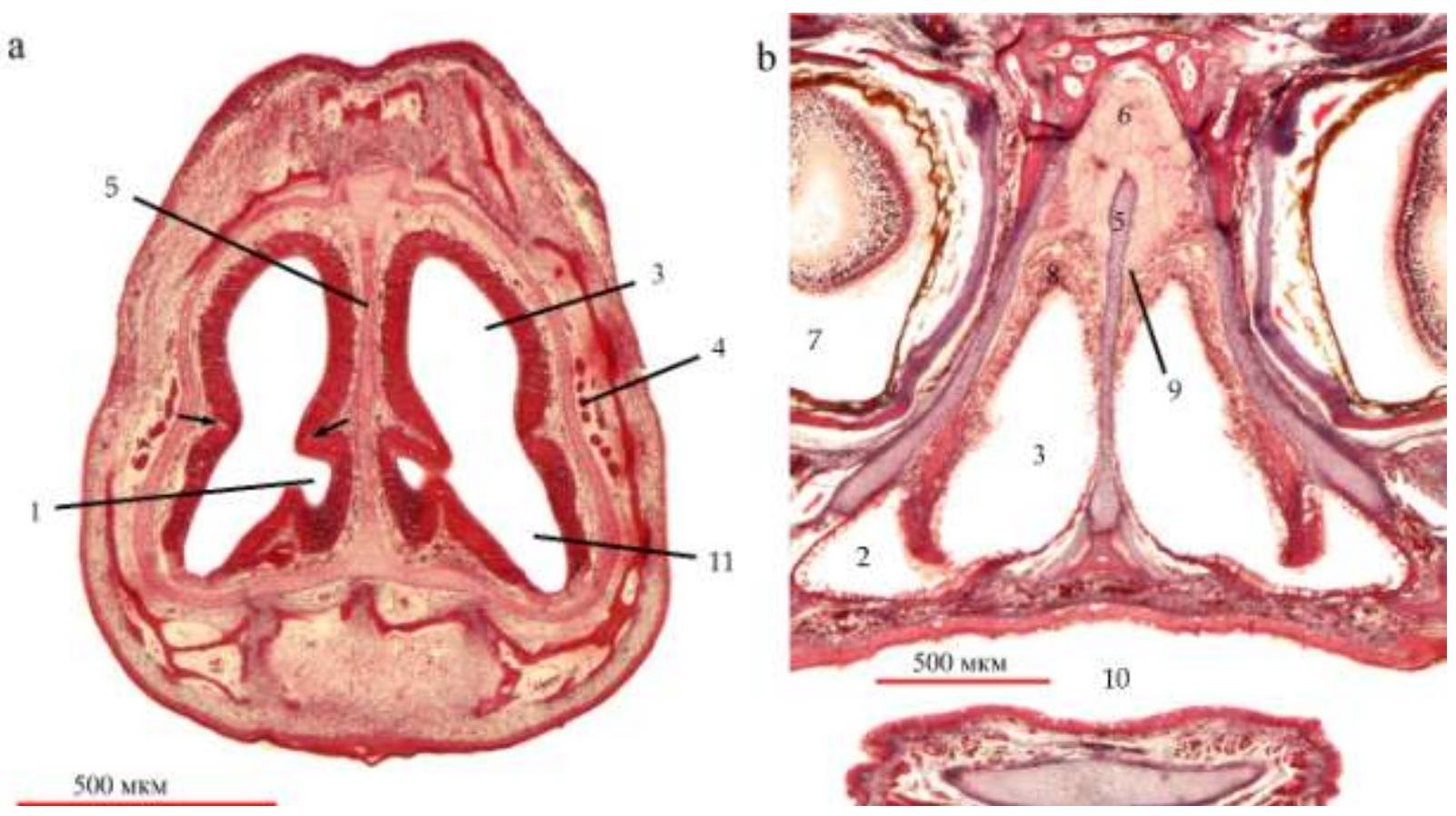

Рис. 2. Поперечний переріз через носову порожнину C. longicollis ембріона 14 мм (a) та ембріона 18 мм (b): 1 -медіальне впячування; 2 - носоглотковий канал; 3 - носова порожнина; 4 -латеральна носова залоза; 5 - носова перегородка; 6 - волокнистий шар нюхових иибулин; 7 - око; 8 -нюховий епітелій; 9 - вомероназальний нерв; 10 - ротова порожнина; 11 -вентральна частина носової порожнини. Стрілками вказано на відсутність сенсорного епітелію.

нюхової та вомероназальної області на цій стадії менш виражена.

Нюховий епітелій утворює чисельні випинання в середину носової порожнини. Нюховий та вомероназальний нерви суттєво збільшуються за рахунок збільшення кількості волокон (рис. 2).

Носоглотковий канал має відносно більшу порожнину та відмежований від основної нюхової порожнини дорсальною епітеліальною складкою (рис. 2). Хоани значно збільшуються в розмірах та мають витягнуту щілиноподібну форму.

Отже, розвиток нюхового органа східної довгошийої черепахи проходить ряд типових для рептилій стадій розвитку. Проте має i власні особливості будови. Нюховий орган черепахи анатомічно не розділений на основну та додаткову нюхові системи. У власне носовій порожнині розрізняють вентральну та дорсальну частини, які розділені вузькою ділянкою несенсорного епітелію. Дорсальна частина вистелена основним нюховим епітелієм, а вентральна вомероназальним епітелієм. Таке розмежування носової порожнини може свідчити про їхню участь у вловлюванні різних одорантів: епітелій вентральної камери - 3 повітря та епітелій нижньої камери - 3 водного середовища. На користь цієї гіпотези вказує наявність латеральної носової залози, секрет якої зволожує нюховий епітелій ростродорсальної частини носової порожнини. Вважаємо, що секрет залози під дією сили тяжіння потрапляє на поверхню вентральної частини носової порожнини, яка вистелена вомероназальним епітелієм.

Таким чином, вомероназальний орган черепахи не відокремлений від основного органа нюху, що вказує на спрощення будови органа нюху в черепах. Одночасно на функціональну значимість вомероназальної системи вказує наявність окремого добре розвиненого вомероназального нерва. Така будова органа нюху черепахи схожа на організацію органа у хвостатих амфібій, зокрема тритона, який веде амфібіотичний спосіб життя. Відомо, що вомероназальний орган $\epsilon$ не у всіх наземних хребетних, він відсутній у крокодилів, птахів, більшості рукокрилих, вторинноводних ссавців та приматів Старого Світу [2; 7; 8;], одночасно дуже розвинений у змій та ящірок [2;9]. Така мінливість організації нюхового органа в різних чотириногих, очевидно, вказує на його різне значення в еволюції та екології виду. 

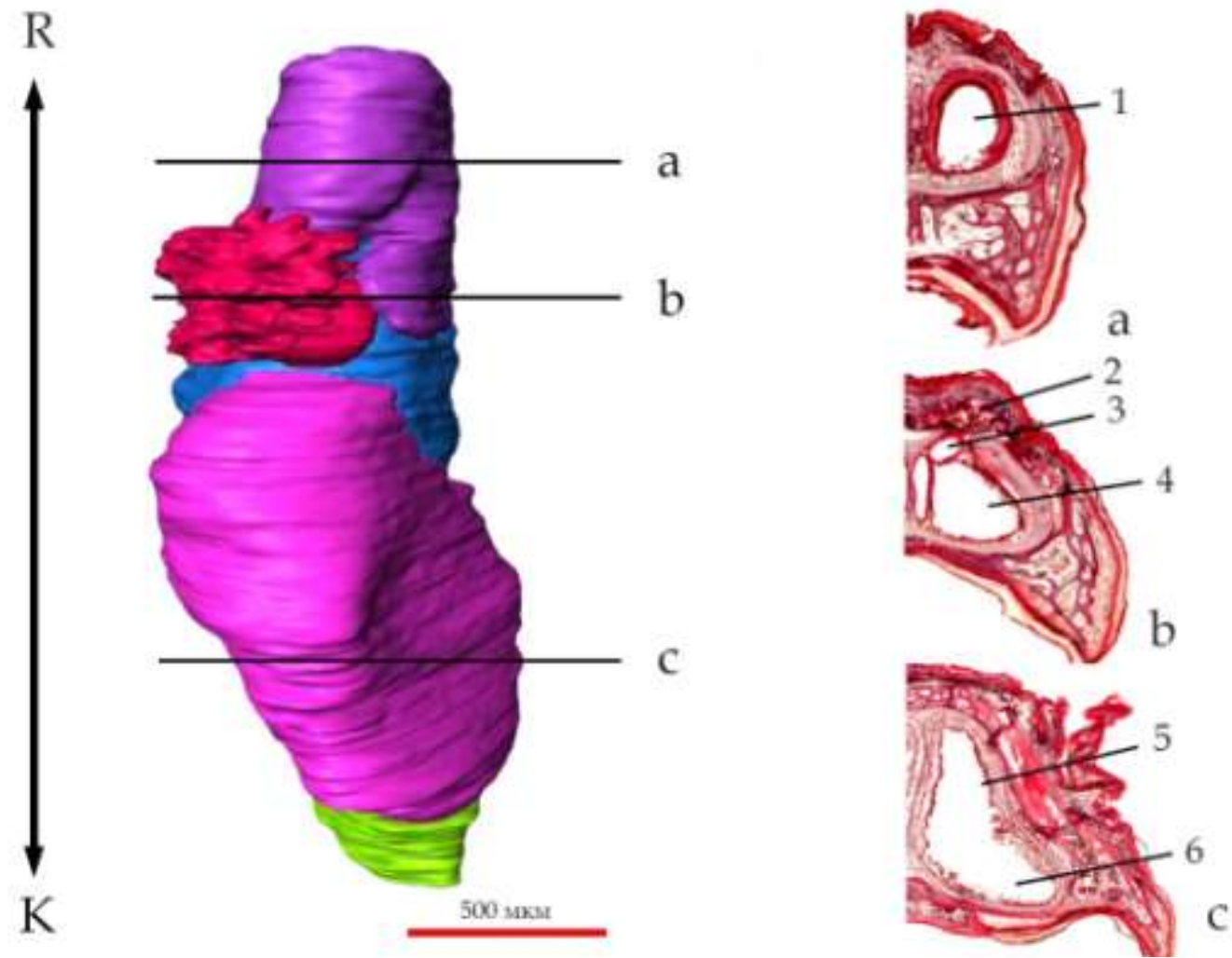

Рис. 3. 3D-реконструкиія органа нюху C. longicollis на стадї 18 мм (дорсальна сторона): aпоперечний переріз через присінок; $b$ - поперечний переріз в місиі впадання латеральної носової залози; c - поперечний переріз через основну носову порожнину; 1 - присінок; 2 -латеральна носова залоза; 3 - протока латеральної носової залози; 4 - перехід вестибулюма у власне носову порожнину;

5 - дорсальна частина носової порожнини; 6 - вентральна частина носової порожнини. $R$ - рострально; $K$ - каудально.

a

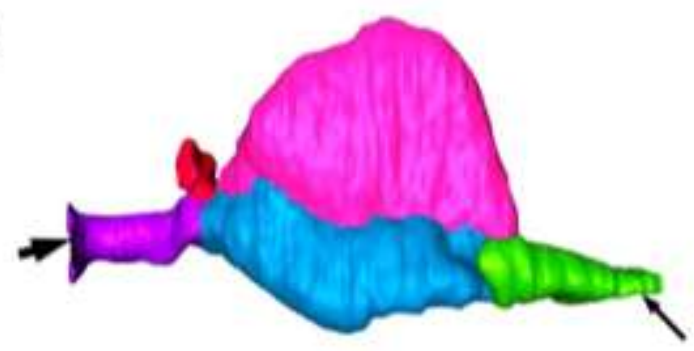

b

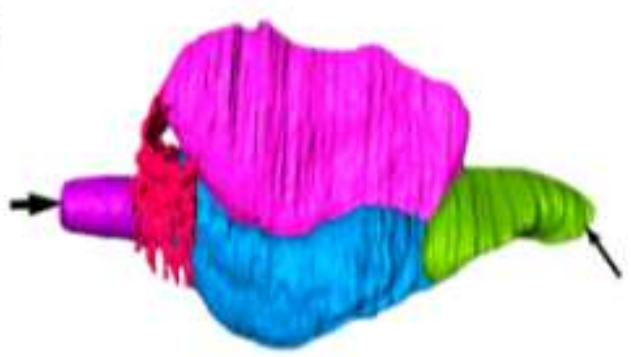

C

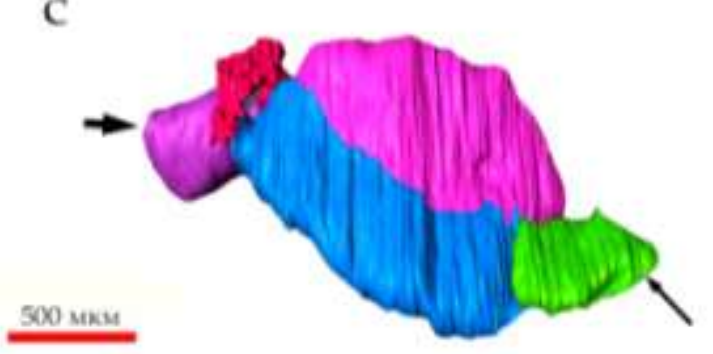

$\mathrm{R} \quad \mathrm{K}$

Рис. 4. 3D-реконструкиії органа нюху на різних етапах ембріогенезу C.longicollis (латеральна сторона): a-стадія 7,8 мм.; $b$-стадія 14 мм.; c-стадія 18 мм. Рожевий-основний нюховий епітелій; блакитний - вомероназальний епітелій; фіолетовий - присінок; зелений-носоглотковий канал; червоний колір - латеральна носова залоза; товста стрілка - зовнішні ніздрі; тонка стрілка внутрішні ніздрі (хоани); $R$ - рострально; $K$-каудально. 


\section{ВИСНОВКИ}

Орган нюху східної довгошийої черепахи C. longicollis поділяється на присінок, який назовні відкривається зовнішніми ніздрями, власне носову порожнину та носоглотковий канал 3 хоанами. Носова порожнина розмежована вузькою ділянкою несенсорного епітелію на дорсальну, яка вистелена нюховим епітелієм, та вентральну, яка вистелена вомероназальним епітелієм. Нюховий епітелій має чисельні залози Боумена, які відсутні у вомероназальному епітелії. Протока латеральної нюхової залози впадає на межі переходу присінка в носову порожнину та зволожує ростральну частину основного нюхового епітелію, який найбільше контактує 3 повітрям. Доказом наявності вомероназальної системи у черепахи слугує наявність вомероназального нерва, окремі волокна якого йдуть від вентральної частини носової порожнини до медіальної поверхні нюхової цибулини.

\section{Подяки}

\begin{tabular}{lrr}
\multicolumn{1}{c}{ Автори статті висловлюють } & подяку \\
Куратору палеонтологічної & колекції \\
Тюбінгенського університету Еберхарда Карла \\
(Нiмеччина), доктору Інгмару Вернебургу (Dr. \\
Ingmar Werneburg) за можливість стажування та \\
pоботу з колекцією тотальних мікропрепаратів.
\end{tabular}

\section{ЛITEPATУРA}

1. Nakamuta, N.; Nakamuta, S.; Kato, H.; Yamamoto, Y. Morphological study on the olfactory systems of the snapping turtle, Chelydra serpentina. Tissue and Cell 2016, 48 (3), p 145-151.

2. Parsons, T. S. Evolution of the nasal structure in the lower tetrapods. American Zoologist 1967, 7 (3), p 397-413.

3. Saito, K.; Shoji, T.; Uchida, I.; Ueda, H. Structure of the olfactory and vomeronasal epithelia in the loggerhead turtle Caretta caretta. Fish Sci 2000, 66, p 409-411.

4. Halpern, M.; Martinez-Marcos, A. Structure and function of the vomeronasal system: an update. Progress in Neurobiology 2003, 70, p 245-318.

5. Hatanaka, T.; Shibuya, T.; Inouchi, J. Induced wave responses of the accessory olfactory bulb to odorants in two species of turtle, pseudemys scripta and geoclemys reevesii. Comparative Biochemistry and Physiology Part A: Physiology 1988, 91 (2), p 377-385.

6. Титюк, О.; Грубий, В.; Степанюк, Я.; Яригін, О. Просторова реконструкція нюхових структур Lacertaviridis за допомогою комп'ютерного моделювання. Науковий вісник Східноєвропейського наиіонального університету імені Лесі Украӥнки 2015, 12 (313), с 99-104.

7. Bertmar, G. Evolution of vomeronasal organs in vertebrates. Evolution 1981, 35, p 359-366.

8. Halpern, M. The organization and function of the vomeronasal system. Annual Review of Neuroscience 1987, 10 (1), p 325-362.

9. Kratzing, J. E. The fine structure of the olfactory and vomeronasal organs of a lizard (Tiliqua scincoides scincoides). Cell and tissue research 1975, 156 (2), p 239-252. 